\title{
The Past in Music: Introduction
}

DOI:

10.1080/17411910600634213

\section{Document Version}

Accepted author manuscript

Link to publication record in Manchester Research Explorer

\section{Citation for published version (APA):}

Bithell, C. (2006). The Past in Music: Introduction. Ethnomusicology Forum, 15(1), 3-16.

https://doi.org/10.1080/17411910600634213

\section{Published in:}

Ethnomusicology Forum

\section{Citing this paper}

Please note that where the full-text provided on Manchester Research Explorer is the Author Accepted Manuscript or Proof version this may differ from the final Published version. If citing, it is advised that you check and use the publisher's definitive version.

\section{General rights}

Copyright and moral rights for the publications made accessible in the Research Explorer are retained by the authors and/or other copyright owners and it is a condition of accessing publications that users recognise and abide by the legal requirements associated with these rights.

\section{Takedown policy}

If you believe that this document breaches copyright please refer to the University of Manchester's Takedown Procedures [http://man.ac.uk/04Y6Bo] or contact uml.scholarlycommunications@manchester.ac.uk providing relevant details, so we can investigate your claim.

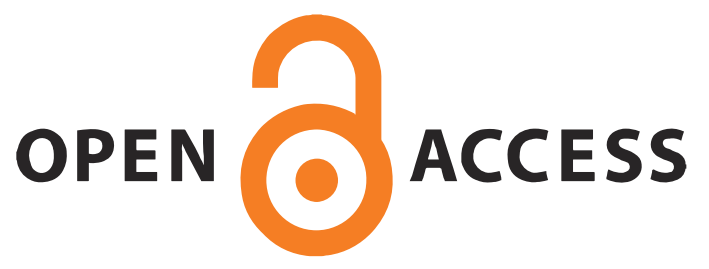




\section{The Past in Music: Introduction}

\section{Caroline Bithell}

University of Manchester, UK

NOTE: This is a post-print (Author's Accepted Manuscript) for:

Bithell, Caroline, 'The Past in Music: Introduction'. In The Past in Music, ed. Caroline Bithell - special issue of Ethnomusicology Forum, vol. 15/1 (2006): 3-16. DOI: $\underline{10.1080 / 17411910600634213}$

In this introduction to a selection of case studies on the theme "the past in music" I offer a few thoughts on the nature of the past and the role of memory in constructing historical narrative, with reference to the way in which these concepts have been theorised by historians, archaeologists, anthropologists and ethnomusicologists. In reviewing the different ways in which echoes of the past can still be heard in the music of the present, I consider the capacity of music to evoke, embody and transform the past and, by so doing, to act as a medium for history and its interpretation.

Keywords: The Past; History; Collective Memory; Archaeology; Musical Heritage; Musical Performance; Oral Tradition; Ritual; Fieldwork; Early Music.

"Typically", to quote Nettl, "ethnomusicology studies the musical culture of a society through the observation of the present" $(1983,176)$. It is this observation, in the guise of fieldwork, which most clearly distinguishes ethnomusicology from historical musicology with its primary interest in musical works created in the past. Yet this does not mean that the past remains forever outside the ethnomusicologist's frame. " "Any picture of the present that is not informed by an appreciation of the historical dimension is," as Widdess notes, "sadly incomplete" (1992, 219). On the surface, fieldwork most often involves direct engagement with the present via observation of contemporary action and interaction with living subjects. Much of what is revealed to us, however, relates as much to the past as to the present. Fieldwork opens doors into the past through memory and narrative, and also through a revisiting of the spaces in which the 
past and its music lived (see Bohlman 1997). Bohlman has proposed that "ethnomusicological fieldwork may ... be at its best when it brings us closer to the fluidity and experiences on the boundaries between past and present" (1997, 141-2). It is these boundaries that are explored in the present volume.

"Archaeology," wrote Sir Mortimer Wheeler in 1954, "is digging up, not things, but people" (cited in Redknap 2002, 27). This is especially true of music, which is so intimately dependent on the presence of human bodies for its manifestation. Unlike items from the material heritage, the sounds of the past cannot be put in a museum, where we might look at them, measure them and compare them one with another. We cannot collect a frozen note or a broken chord and preserve it in a glass cabinet. In the absence of a written tradition or a means of recording the sounds themselves for posterity, music is "visible" only in the moment of its performance.

This is not to suggest that the music of the past leaves no tangible trace. Buckley's 1998 edited volume Hearing the Past set out "to explore ways of developing the study of music in prehistory and early historical societies" on the basis of artefacts such as sound tools, hieroglyphs and occasional literary references and iconographic representations. In the present volume, however, we are less concerned with establishing what the past sounded like or "how music really was" in the past. Our aim rather is to explore the ways in which echoes and legacies from the past can still be heard in the present and to consider the extent to which musical practices in the present are shaped not only by past experience but also by ideas, feelings and beliefs about the past.

Musical and other types of performance occupy a special position in small-scale, non-literate societies where "history can only be created and interpreted through repeated performances" (Seeger 1993, 24). Performance, particularly in the context of ritual, reaffirms the past and keeps it alive; it is through such performance that music is able to function as "the crucible in which time and its memories are collected, reconstituted, and preserved" (Neuman 1993, 269) and that "an individual in the present [is able] to re-sing, re-hear, and re-experience the past" (Shelemay 1998, 223). At the same time, performance does not constitute a simple revisiting of the music of the past. The music itself is "made" anew at each rendition. In the moment of resounding it is fully and incontrovertibly part of the present. 


\section{Constructed Pasts, Contested Histories and Collective Memory}

Before we consider further the ways in which echoes of the past are immanent in the music of the present, it will be instructive to reflect on the nature of the past itself. It may well be a truism to say that there's no escaping the past. "Whether it is celebrated or rejected, attended to or ignored, the past is omnipresent" (Lowenthal 1985, xv). Not only is it all around us, in the contours of our landscapes and the fabric of our cities. It is in our bones and our blood; no matter how hard we may try to erase or forget it, it insinuates itself into our dreams. But when was the past? Was it yesterday, a generation ago, a century or a millennium ago? And who lived there? Kings and queens, bishops and generals, blind bards and foot soldiers, hunters and gatherers, farmhands and factory workers, heroes and the condemned. Clearly, there is nothing homogeneous about the past.

A number of writers concerned with historical perspectives have proposed models for distinguishing different levels of past-ness. Romero, for example, identifies three kinds of past operating in the Andean community in which he worked: "a ritual, noncontested past, a precapitalist agricultural past, and a 'modern' past" $(2001,145)$. This model builds on Geertz's identification of a ritualised, timeless past, distinguished from a non-ritual, mundane past that has an objective and uncontested duration (Geertz 1966). In critiquing Geertz's model and its later modification by Bloch (1977), Appadurai went on to propose "a third kind of past whose essential purpose is to debate other pasts" $(1981,202)^{2}$

As the exponents of interpretative archaeology - following in the wake of interpretative anthropology - have gone on to argue, "there is no final and definitive account of the past as it was" (Shanks and Hodder 1995,5) but instead a plurality of interpretations which take account of the interests, needs and desires of a range of different constituencies. Different pasts and their meanings co-exist. Part of the attraction of "the past" in our own age is that it presents us with "an infinity of alternative worlds" (Butt 2002,171) onto which we can project a multitude of meanings and interpretations. We are free to choose the face of the past in which we recognise our own present or future. ${ }^{3}$

The past, then, is a source of cultural symbols that have a power beyond mere history. Hence the theorisation of the past - by historians, archaeologists and 
anthropologists alike - as a construction of the present, with both past and future viewed as ideational or representational. "Memory, history, and relics of earlier times shed light on the past," writes Lowenthal. "But the past they reveal is not simply what happened; it is in large measure a past of our own creation, moulded by selective erosion, oblivion, and invention" (1985, inside front cover). Similarly Chapman, McDonald and Tonkin $(1989,5)$ : "In order to account for the present, to justify it, understand it, or criticize it, the past is used, selectively appropriated, remembered, forgotten, or invented." Even with the best of intentions there is always an element of hypothesising, reconstructing or imagining. In time, myths take on a life of their own; beliefs acquire a greater "reality" than objective proofs. In Kammen's oft-quoted formulation, "what people believe to be true about their past is usually more important in determining their behaviour and responses than truth itself" (1991, 38-9). In some cases such beliefs have the status of shared memories which, however, "are not memories at all, but rather shared presumed memories or histories" which can nonetheless "remain alive across generations - often in the face of contradictory evidence" (Pennebaker 1997, vii). It is the meaning invested in assumed memories of the past that gives present actions their rationale. The present may be unimaginable without the past, but it is the present that calls the shots.

It is these multi-faceted, contested and sometimes conflicting interpretations of the past that so often surface in fieldwork. As Shelemay observes, "Ethnography militates against assumptions about the way things were and ... can help us 're-envision the past' differently. It informs the fieldworker about the vagaries of individual initiative, underscoring the reality of divergent perspectives even in the face of seeming unanimity" $(2001,23) .{ }^{4}$ What our interlocutors tell us reveals not only different aspects of the past but also the mechanisms by which the past is remembered, constructed and invested with meaning (see further Shelemay, this volume).

The malleability of the past derives in part from the nature of memory itself. "Memory," writes Shanks, "is not like a journal, an objective record of life in the sequence it occurred. Memory is of the present and a disorder of select moments, impressions and subjective states" $(1992,101)$. Different types of memory are discussed in greater detail in the case studies that follow. Of particular interest in the present context is a growing body of literature addressing the question of how societies (as opposed to individuals) remember. Connerton, in his theorisation of social or collective 
memory, focuses on what he refers to as incorporating practices, as distinct from inscribing practices. Inscribing practices make use of devices for storing and retrieving information (print, indexes, photographs, sound tapes, computers, etc.) - devices which continue to exist "long after the human organism has stopped informing" (Connerton 1989, 73). Incorporating practices, by contrast, involve messages imparted by current bodily activity, with memory being "sedimented, or amassed, in the body" $(1989,72)$; in this case transmission requires bodies to be present. Incorporating practices are clearly a key feature of societies that rely on oral transmission. At the same time they are by no means excluded from literate societies, where they often exist alongside more conventional archival practices. ${ }^{5}$

Assman's identification of two modes of remembering the past - "communicative memory" and "cultural memory" - that are involved in the construction of collective memory recall the different levels of past-ness referred to above. "Communicative memory" refers to the recent, more concrete past, while "cultural memory" refers to the distant past, with ritual playing a primary role in its organisation. "Cultural memory" includes "memory culture", referring to the way in which traditions passed down from generation to generation with the aid of cultural mnemonics ensure cultural continuity, and "reference to the past", which nurtures a sense of collective identity based on a "shared past" (Assmann 1992, as summarised in Randhofer 2004, 38-9).

These and other landmark contributions to the study of social or collective memory notwithstanding, Urry laments the dearth of analysis of "the precise mechanisms by which societies remember and incorporate the past into the present". "What," he asks, "are the different mechanisms by which this remembering occurs in different kinds of society? How do these remembering processes within different societies do their work, not just at levels of ideas but of bodies, not just of ideologies but of practices, not just of images but of interpellated 'temporal' subjects?" $(1996,46)$. The papers in this volume will, we hope, provide some illuminating answers. ${ }^{6}$

\section{Music, Tradition and the Past in the Present}

One of the principal contributions of ethnomusicology to the study of modern history is the recognition that musical power remains a vital source of nourishment for many of the world's peoples. Without the empowerment 
gained through music, it is impossible to keep the past alive in the present, or to recognise and respond to the realities that are transforming the present into the future.

(Blum 1993, 9)

Music can both reference the past and carry it forward in numerous ways. The frequent association of music with tradition or ritual naturally ensures some degree of continuity with the past. Rituals of collective music-making in general are driven not by a search for individuality and novelty but by an underlying stability that, in some cases, is seen as a precondition of the ritual's efficacy, even if "the absolutely static is inconceivable" (Nettl 1983, 177). While surface aspects of a musical repertoire might clearly evolve, more ingrained features of style and performance practice - such as a particular quality of timbre or technique of ornamentation - can still be in direct continuity with past practice. $^{7}$

In many societies history is literally sung, a circumstance highlighted in Africa and elsewhere by the representation of the poet-singer as a library (as in the oft-quoted maxim "When a griot dies, it's like a library burning down"). Historical events are commonly recounted by means of epic narration or ballads; they may also be debated and interpreted through song, often with the help of metaphor and satire. Similarly, many dance performances re-enact some (pseudo)historical event, such as an arrival, an encounter, a battle or a conquest (e.g. the moresca as still performed in the Mediterranean region, which depicts the victory of the Christians over the Moors).

Seeger (1993) has shown how the Suyá Indians, in a very different way, archive in their musical repertoire the history of their encounters with "powerful strangers" via a direct appropriation of these strangers' songs, which are then incorporated into their own ceremonies. In other societies new additions to the musical repertoire are viewed not as being composed in the present but as being transmitted by the ancestors; the living are essentially a medium for the voices of the dead, who themselves play an active part in the affairs of the present. Through their song-lines and other rituals associated with the Dreaming, Australia's aboriginal peoples retrace the steps of history and keep alive the original moment of creation by re-singing the songs bequeathed to them by the "powers". 
Other types of performance reference past performances by means of allusion or pastiche, bringing together different pasts and recontextualising them in the present. Bohlman evokes the multivalent nature of the past when he speaks of music acquiring "a 'poetics of memory,' wherein various pasts otherwise separate will converge and even coexist" (Bohlman 2003, 302, referencing Slyomovics 1998, 169-98). Emoff describes how in tromba possession ceremonies on the east coast of Madagascar fragments of different times and places might overlap, while the music performed during the ceremony "facilitates the actual evanescence of temporal delimitations between past, present, and future" $(2002,8)$. East coast Malagasy "not only relive but refigure their pasts by recollecting (from) them" (107).

Revival movements, by definition, aim to resurrect earlier practices that have fallen out of fashion or circulation. Typically, revivals are motivated as much by ideological as by aesthetic considerations. For their instigators, the traditions of the past offer a welcome refuge from the complexities and confusions of modern life, serving as an anchor in the storm that threatens to tear identities from their roots. In the course of the past century social stability in many parts of the world has been profoundly affected by war, emigration, urbanisation, secularisation, industrialisation, professionalisation, the growth of media and tourism, and the expansion of markets. In reaction to the ensuing sense of dislocation, local communities have turned their attention to reclaiming, restoring or revitalising rituals from the past as a means of reforging a community spirit and investing individual action with meaning. ${ }^{8}$ The urge to re-tread the paths of the past does not, however, necessarily reflect resistance to the modern or fear of the new. A return to earlier traditions can also follow in the wake of independence or regime change, allowing the revivalists to shape a new present while re-establishing continuity with a past of their own choosing and moving towards a future of their own making - a project that can, even as it looks to the past, be driven by a modernising ethos (see, for example, Waterman's account of the intersecting processes of indigenisation and modernisation in the development of modern jùjú in Nigeria [1990]). ${ }^{9}$

Musical choices can also be part of the process whereby people in the present choose or construct a history that meets their current needs. This is most commonly seen in association with the rise of nationalist movements. "The discovery of a national past whether real or imagined - binds fractured communities together by giving them a new 
sense of a common heritage" (Smith 1996). Music is a powerful tool for binding communities together in this way. It can also be harnessed to keep histories separate; musical style defines not only who people are but also who they are not. In nationalist contexts, traditional musical styles and repertoires are mobilised both as reminders of a heroic past and as sonic markers of a separate identity. The war in former Yugoslavia offers one of the clearest examples of the way in which contested interpretations of the past, together with disagreement over the ownership of its cultural symbols, become crucial to present struggles, and the way in which music becomes implicated in ethnic conflict. Among diasporic communities, meanwhile, music keeps alive links with a lost homeland and a past that may be at odds with present reality.

At the same time as keeping some aspect of the past alive, music can also function as a symbol of resilience and survival, as in the case of the Mostar Sevdah Reunion Band, which - following the destruction of the Bosnian town of Mostar reunited musicians who had different ethnic backgrounds (Bosnian, Serbian and Croatian) but a shared musical heritage. "They destroyed our town," the band's manager, Dragi Sestic, is quoted as saying, "but they couldn't destroy our music. They couldn't destroy sevdah". Mira Erdevicki, director of the documentary film The Bridge of Bosnian Blues, elaborates: "It's so much more enduring than politicians like Tudjman or Milosevic. You can devastate a country, kill a lot of people, but you can't devastate the spirit. And that's what sevdah is, a spirit" (both speakers cited in Broughton 2004, 33$5){ }^{10}$

Finally, the continued currency of supposedly "old" or "earlier" styles (i.e. those that continue to use elements of a musical vocabulary that might be seen, from an evolutionist perspective, to have been superseded by more "modern" conventions or idioms) can represent an alternative worldview to that predicated on a linear view of history driven by progress and betterment. Music makes manifest the way in which groups of people can challenge the discourse of modernity and its claim to the present by enacting a parallel, contemporaneous present informed by different values. Musical performance offers itself as an ideal site for the deconstruction of the too-easy opposition of past and present, old and new, traditional and modern. 


\section{And So To This Volume}

The authors of the essays presented here raise and respond to a range of questions concerning music's relationship with the past. What role does music play in relation to history? In what ways does music embody and evoke memories of the past? In what ways has the past been mobilised, through musical performance, by particular groups of people and for what ends? What can present day practices tell us about how music might have sounded in the past? What kinds of procedures and methodologies have been employed in projects aimed at reconstructing sounds and repertoires from the past? To what extent, and at what levels, might we assume continuity of practice between past and present within a single music culture? What does it mean to talk of "archaisms" in the style of a present-day music culture?

As already noted, ritual enactment is considered central to the transmission and maintenance of social memory, with religious festivals in particular functioning as sites of remembrance (Connerton 1989,46). It is perhaps not surprising, then, that three of the papers in the present collection (Bithell, Reily and Shelemay) are concerned with the music of religious ritual. Reily examines the way in which historical consciousness has been constructed and sustained through the Holy Week celebrations in Campanha, a former gold-mining town in the Brazilian state of Minas Gerais. These rituals, Reily argues, allow participants to re-experience their visions of a more grandiose, baroque past, whose "memories ... sustain hopes for a glorious, golden future". The musical repertoires that have traditionally accompanied the various ceremonies and have accrued prestige on account of their assumed (and to some extent contested) origins have, however, come under threat in recent years due to the modernising project of the Catholic church with its move to congregational singing in a more "popular" idiom. Reily describes how "confrontations between church officials and the faithful ... have heightened local historical consciousness, but they have also drawn attention to the distinct conceptions of history held within the town" - differences that also "rest upon disparate orientations to religiosity itself".

My own paper takes as its subject polyphonic settings of the Latin mass preserved in oral tradition in the Mediterranean island of Corsica but, like the traditions described by Reily, struggling to stand their ground in the face of the church's 
modernising mission. Drawing on a series of metaphors and paradigms from the fields of archaeology and heritage conservation, I explore the processes involved in the recent retrieval and reconstruction of certain of these masses (of which only fragments remained in the memories of surviving singers), interrogating the different motivations, methodologies and ideologies of the various parties involved and considering what different approaches to, and subsequent uses of, the material reveal about different attitudes towards the past. A subtheme of my discussion is the way in which local identity, and hence the "authenticity" and "meaning" of an interpretation of a mass associated with a particular village, is seen to be constituted by fine nuances of singing style and performance practice, such that "It is never enough to excavate or to reproduce only the melody line of a piece. ... Only as the full palette of para- and extramusical factors comes into play do the fragments begin to assume form and colour." Charting the way in which the revived repertoires have been reabsorbed into the living tradition, I argue that "the renewed practice of singing the mass in the 'old way" - like the creation of new material in what outsiders might view as an "archaic" musical idiom - "should be viewed as an authentic part of the Corsican present".

I began this essay with reference to fieldwork's capacity to open doors into the past. Bohlman further comments on the way in which fieldwork can "attempt to locate musical knowledge that conveys a sense of self in its relation to the past" $(1997,152)$. Shelemay's paper draws on her work with members of the Syrian Jewish community who maintain the tradition of pizmonim (paraliturgical hymns in Hebrew) in the disaporic setting of Mexico City. Adapting a strategy suggested by scholars of "the new historicism", she uses "a statement made at a single ethnographic moment as a point of departure for both exploring a site of memory and anchoring historical discourse". An individual pizmon serves to illustrate "the ways in which individual and collective memories are fashioned into the texts, tunes and performance practice of this song repertory", while "the manner in which the song entered into discussion during the interview provides a salient example of the ways in which memories become marked for, and transformed into, historical narratives through the ethnographic interview". This exploration of "the interactive relationship of memory and history during the ethnographic research process" prompts Shelemay to reflect on the "ways in which ethnomusicologists are instrumental both in eliciting memories and in constructing historical narratives". "Ethnomusicologists," she argues, "must consider themselves 
able and empowered to study history and to explore fully the ability of music to inform us about the past."

Thomas has observed that, in the postmodern relationship with the past, "the past is often thought about, analysed, circulated as a set of commodities, but less often simply felt" $(1995,356)$. In the case of music the "feeling" of the past can be at its most intense. This is especially so when "lost", forgotten, abandoned or previously forbidden music is heard again in its original location, as in the Mostar example cited above. In my own paper, I refer to the emotion evoked by the first re-sounding of mass settings that had not been heard for a generation or more. The part played by emotion in the processes of remembering is a central theme of Shelemay's paper, as reflected in one of its sub-headings, "Meaning a lot and making me feel". Comments made in interviews, Shelemay observes, "reveal the manner in which musical experience is sustained in memory as both a sound world and an affect-laden recollection of the past". Reily also describes the strong affective links that many of the people in her own study have toward long-standing repertoires and practices, while emphasising the critical part played by performance experience in shaping historical consciousness.

Professional performing artists can play a special role in re-voicing the past in the present. French singer-songwriter Yves Simon has spoken of the artist as an "archaeologist of knowledges, memories and imaginaries" who both reinvents the past and links it to the present and future (Looseley 2003, 50). Muller has also focused on contemporary composition and performance as storage device. Drawing on Derrida's integration of memory and archiving as dual sites and practices of the human mind (Derrida 1995), she expands on the conventional definition of the archive (usually associated with Connerton's inscribing practices) with her suggestion that "song composition provides a mechanism for archival deposit, care, and retrieval in contexts of immanent [sic] loss" $(2002,409)$. In her contribution to the present volume she expands on her earlier notion of spectral voices intervening in the present (2002) as she explores the world of jazz singer Sathima Bea Benjamin, transposed from her native Cape Town in South Africa to New York City. A particular concern here is the manner in which sounds, voices and memories from different layers of Benjamin's own past are embodied in recorded performances, with the recording studio operating as "a kind of modern dream space" in which "Sathima's vision of the ideal recording event is shaped out of the bodily archive of prior performances transformed into a new musical 
texture". From her location in the new African diaspora, Benjamin exemplifies "a particular approach to jazz that invokes both a personal past and collective memory of bygone eras of popular music and jazz performance". Elaborating on Benjamin's formulation of music as "the spirit within you" (from her song "Music"), Muller argues that "music as spirit is a recyclable resource for present performance: it sets the past in motion". This leads her to propose a new way of thinking about jazz historiography by conceiving of jazz's past "as a more flexible and usable archive or as a 'living history'".

If the past can be seen as holding keys that can unlock the meaning of the present, then equally, in the words of James Hutton, "the present is the key to the past" (cited in Hayden 1993, 85). The basic tenets of uniformitarianism - the theory formulated by Hutton and others in the late $18^{\text {th }}$ and early $19^{\text {th }}$ century and used by both archaeologists and geologists to explain events in the past through observation of processes operating in the present - also inform ethnoarchaeology, which attempts to resolve archaeological problems through observation of present-day "traditional" societies (see further Hayden 1993, 122ff). A similar approach has been adopted by the Early Music performers who are the subject of Shull's paper. Shull describes how, as part of the project to reconstitute a historically informed performance of medieval repertoires ("the residues of which survive only in spare descriptive notations and fleeting literary references"), Thomas Binkley and others who followed his lead (including Benjamin Bagby, Joel Cohen and Angela Mariani) have turned to living oral traditions "as a sonic, as well as technical, resource for the (re)establishment of new 'old' practices". Having "recourse to the sound and practice of a present 'other' to inform a past 'other'", artists such as Cohen have advocated direct collaboration with contemporary culture-bearers whose present-day practice is assumed to retain some degree of continuity with the past at the level of style and interpretation, even if the repertoires themselves have not survived in the living tradition. Shull stresses the ethical consciousness of these artists, who "hold their informants and collaborators in high esteem and treat their beliefs with respect". At the same time, Cohen concedes that "every performance is a hypothesis. There's no such thing as a definitive performance..."

This thought brings us back full circle to the notion of a polyphonic, multivalent past, creatively revitalised, interpreted and transformed by individuals in the present informed, nonetheless, by an inherited historical consciousness. In the pages that follow, we reflect on the seemingly inexhaustible capacity of oral genres to reverberate between 
(different) past(s) and present(s) (Coplan 1993, 45) as we investigate just some of the many ways in which the voices of the past live on in the music of today.

\section{Acknowledgements}

The articles brought together in this volume all began life as papers read at the annual conference of the British Forum for Ethnomusicology hosted by the University of Wales, Bangor in May 2003. Wyn Thomas, Jochen Eisentraut, David Wong and Jonathan Stock were key players in the preparation, organisation and smooth running of the conference, which also benefited from the generous support of the Archive of Traditional Welsh Music. A highlight of the gathering was the keynote lecture given by Kay Kaufman Shelemay, a version of which is also included here. I am grateful to all of my co-authors for their enthusiasm for this project and for their good-natured cooperation during the lengthy process of preparing their contributions for publication; it has been an honour to work with each and every one of them. Thanks are also due to the journal's general editors, Tina K. Ramnarine and Rachel Harris, to the referees of the individual articles for their meticulous readings and invaluable feedback, and to Martin Clayton for the formulation 'The Past in Music'.

\section{Notes}

Caroline Bithell ( $\mathrm{PhD}$ Wales) is Lecturer in Ethnomusicology at the University of Manchester, UK. Drawing on her research into Corsican music, she has published a number of journal articles and book chapters spanning a range of thematic and theoretical areas, including oral traditions of vocal polyphony, the revival and reconstruction of traditional repertoires, the commercialisation and professionalisation of traditional music, music and gender, music and nationalism, and the politics of fieldwork and ethnography. Her book Transported by Song: Corsican Voices from Oral Tradition to World Stage is shortly to appear in Scarecrow Press's series Europea: Ethnomusicologies and Modernities. Correspondence to: Music, Martin Harris Centre for Music and Drama, The University of Manchester, Coupland Street, Manchester M13 9PL, UK. Email: Caroline.Bithell@manchester.ac.uk 
${ }^{1}$ I am not suggesting that any such notion is implied by Nettl. In his prelude to The Study of Ethnomusicology, from which my opening quote is taken, he proposes that "the value and contribution of ethnomusicology" are "essentially and very broadly historical" $(1983,11)$. Ethnomusicologists have long been interested in processes of change, attempting to understand how, and why, the present differs from the past. The extent to which an understanding of historical processes is crucial to an appreciation of why music has developed in a certain way and what it has come to mean has been expertly demonstrated in a number of ethnographies (e.g. Waterman 1990, Rice 1994, Erlmann 1996, Rees 2000, Turino 2000, Jones 2004).

${ }^{2}$ This past - later referred to as "a third aspect of the past" - is culture-specific and "consists of a set of norms whose sole purpose is to regulate the inherent debatability of the past in the present" (Appadurai 1981, 218). See further note 3.

${ }^{3}$ This is not to say that the choice is an entirely free one. As early as 1981, Appadurai had already challenged the anthropological assumption that "the past is a limitless and plastic symbolic resource, infinitely susceptible to the whims of contemporary interest and the distortions of contemporary ideology" $(1981,201)$ in his paper "The Past as a Scarce Resource" (referred to above), where he argued that "there is a minimal set of formal constraints on all [...] sets of norms [about the past]" (203). These constraints implicated in the notion of debating the past - are constituted by the four "dimensions" of Authority, Continuity, Depth and Interdependence, which typically involve "cultural consensus" over the requirements for "minimal credibility" (203). This normative framework "permits an orderly symbolic negotiation between 'ritual' pasts and the 
contingencies of the present" ensuring that "when change does occur, it is not entirely at the cost of cultural continuity" (218).

${ }^{4}$ Shelemay is alluding here is to Jeffery's Re-envisioning Past Musical Cultures: Ethnomusicology in the Study of Gregorian Chant (1992).

${ }^{5}$ To give an example of the way in which, in the musical realm, written records can be supplemented by unique testimony from oral tradition, Widdess observes that "in India ... musical treatises rarely concern themselves with performers as individuals, about whom there is however a rich oral history" $(1992,220)$.

${ }^{6}$ The literature on memory across the social sciences did, of course, continue to snowball throughout the 1990s. Notable contributions include Lipsitz 1990, Middleton and Edwards 1990, Schudson 1993, Pennebaker, Paez and Rimé 1997, Nora 1997, Bal, Crewe and Spitzer 1999, Misztal 2003, Radstone and Hodgson 2003, Ricoeur 2004, and Erll and Nünning 2004. Two classic texts, Halbwachs 1925 and 1950, were also republished in new editions (in 1994 and 1997 respectively). For an analysis of the reasons for the upsurge of interest in memory over the past two decades, see Nora 2002. On the relationship between memory and history, see Nora 1989 and 2002 and Hutton 1993. Musical ethnographies in which memory is a central theme include Shelemay 1998, Romero 2001, Emoff 2002 and Harris 2004. (I am grateful to Gerda Lechleitner for drawing my attention to Nora 2002 and Erll and Nünning 2004.) 
${ }^{7}$ I do not mean to imply here any kind of essentialised conception of style. As Emoff observes, within any given culture different styles can be "differentiated ... and connected to dissimilar pasts" $(2002,169)$. See also my own discussion in Bithell 2005.

${ }^{8}$ The wave of ritual escalation across Europe in the 1960s and 1970s has been well documented in the anthropological literature: see, for example, Boissevain 1992.

${ }^{9}$ A fascinating variation on the theme of re-establishing continuity with a past of one's own choosing is presented by cases where the past is not simply selectively remembered but is actively misremembered, as, for example, de Jong argues in her discussion of the comback party adopted by Afro-Curaçaoans as a means of enacting their selfidentification as Cuban (de Jong 2003).

${ }^{10}$ The Bridge of Bosnian Blues was broadcast in the UK on BBC 4 in December 2004.

\section{References}

Appadurai, Arjun. 1981. The past as a scarce resource. Man 16 (2): 201-219.

Assman, Jan. 1992. Das kulturelle Gedächtnis: Schrift, Erinnerung und politische Identität in frühen Hochkulturen. München: C. H. Beck.

Bal, Mieke, Jonathan Crewe and Leo Spitzer (eds). 1999. Acts of memory: cultural recall in the present. Hanover, NH: University Press of New England.

Bithell, Caroline. 2005. Anchors and sails: music and culture contact in Corsica.' In The Mediterranean in music: critical perspectives, common concerns, cultural differences, 
edited by David Cooper \& Kevin Dawe. Lanham, MA and Oxford: The Scarecrow Press, pp. 155-77.

Bloch, Maurice. 1977. The past and the present in the present. Man 12: 278-92.

Blum, Stephen. 1993. Prologue: ethnomusicologists and modern music history. In Ethnomusicology and modern music history, edited by Stephen Blum, Philip V. Bohlman and Daniel M. Neuman. Urbana and Chicago: University of Illinois Press, pp. 1-20.

Bohlman, Philip V. 1997. Fieldwork in the ethnomusicological past. In Shadows in the field: new perspectives for fieldwork in ethnomusicology, edited by Gregory F. Barz and Timothy J. Cooley. New York and Oxford: Oxford University Press, pp. 139-162. 2003. Sacred popular music of the Mediterranean and the journey to Jerusalem.

In Mediterranean mosaic: popular music and global sounds, edited by Goffredo Plastino. New York and London: Routledge, pp. 287-306.

Boissevain, Jeremy (ed). 1992. Revitalizing European rituals. London and New York: Routledge.

Broughton, Simon. 2004. Band over troubled water: Mostar Sevdah Reunion. Songlines 27: 33-35.

Buckley, Ann (ed.). 1998. Hearing the past: essays in historical ethnomusicology and the archaeology of sound. Liège: Etudes et Recherches Archéologiques de l'Université de Liège.

Butt, John. 2002. Playing with history: the historical approach to musical performance. Cambridge: Cambridge University Press.

Chapman, Malcolm, Maryon McDonald and Elizabeth Tonkin. 1989. Introduction history and social anthropology. In History and ethnicity, edited by Elizabeth 
Tonkin, Maryon McDonald and Malcolm Chapman. London and New York:

Routledge, pp. 1-21.

Connerton, Paul. 1989. How societies remember. Cambridge: Cambridge University Press.

Coplan, David B. 1993. Ethnomusicology and the Meaning of Tradition. In

Ethnomusicology and Modern Music History, edited by Stephen Blum, Philip V.

Bohlman and Daniel M. Neuman. Urbana and Chicago: University of Illinois Press, pp. 35-48.

Derrida, Jacques. 1995. Archive fever: a Freudian impression. Chicago: University of Chicago Press.

Emoff, Ron. 2002. Recollecting from the past: musical practice and spirit possession on the east coast of Madagascar. Middletown, Conn.: Wesleyan University Press.

Erll, Astrid and Ansgar Nünning (eds). 2004. Medien des kollektiven Gedächtnisses: Konstruktivität - Historizität - Kulturspezifizität. Media and Cultural Memory, Bd. 1. Berlin and New York: Walter de Gruyter.

Erlmann, Veit. 1996. Nightsong: performance, power, and practice in South Africa. Chicago and London: University of Chicago Press.

Geertz, Clifford. 1966. Person, time and conduct in Bali: an essay in cultural analysis. Yale Southeast Asia Program, Cultural Reports Series, \# 14.

Halbwachs, Maurice. 1925. Les cadres sociaux de la mémoire. Paris: Librairie Félix Alcan.

(New edition: Albin Michel, 1994.) . 1950. La mémoire collective. Paris: Presses Universitaires de France. (New edition: Albin Michel, 1997.)

Harris, Rachel. 2004. Singing the village: music, memory and ritual among the Sibe of Xinjiang. Oxford and New York: Oxford University Press, for the British Academy. 
Hayden, Brian. 1993. Archaeology: the science of once and future things. New York: W.H. Freeman \& Company.

Hutton, Patrick H. 1993. History as an art of memory. Hanover, NH and London: University Press of New England.

Jeffery, Peter. 1992. Re-envisioning past musical cultures: ethnomusicology in the study of Gregorian chant. Chicago and London: University of Chicago Press.

Jones, Stephen. 2004. Plucking the winds: lives of village musicians in old and new China. Leiden: Chime.

Jong, Nanette de. 2003. Forgotten histories and (mis)remembered cultures: the Comback party of Curaçao. British Journal of Ethnomusicology 12 (2): 35-50.

Kammen, Michael. 1991. Mystic chords of memory: the transformation of tradition in American culture. New York: Alfred A. Knopf.

Lipsitz, George. 1990. Time passages: collective memory and American popular culture. Minneapolis and London: University of Minnesota Press.

Looseley, David L. 2003. Popular music in contemporary France: authenticity, politics, debate. Oxford and New York: Berg.

Lowenthal, David. 1985. The past is a foreign country. Cambridge: Cambridge University Press.

Middleton, David and Derek Edwards. 1990. Collective remembering. London: Sage. Misztal, Barbara. 2003. Theories of social remembering. Maidenhead: Open University Press.

Muller, Carol A. 2002. Archiving Africanness in sacred song. Ethnomusicology 46 (3): 409431. 
Nettl, Bruno. 1983. The study of ethnomusicology: twenty-nine issues and concepts. Urbana and Chicago: University of Illinois Press.

Neuman, Daniel M. 1993. Epilogue: paradigms and stories. In Ethnomusicology and modern music history, edited by Stephen Blum, Philip V. Bohlman and Daniel M. Neuman. Urbana and Chicago: University of Chicago Press, pp. 268-77.

Nora, Pierre. 1989. Between memory and history: les lieux de mémoire. Translated by Marc Roudebush. Representations 26: 7-25. . 1997. Realms of memory: the construction of the French past. New York: Columbia University Press. . 2002. The reasons for the current upsurge in memory. http:/ / www.eurozine.com/article/2002-04-19-nora-en.html Accessed 16 Aug. 2005.

Pennebaker, James W., Dario Paez and Bernard Rimé (eds). 1997. Collective memory of political events: social psychological perspectives. Mahwah, NJ: Laurence Erlbaum Associates.

Pennebaker, James W. 1997. Introduction. In Collective memory of political events: social psychological perspectives, edited by James W. Pennebaker, Dario Paez and Bernard Rimé. Mahwah, NJ: Laurence Erlbaum Associates, pp. vii-xi.

Radstone, Susannah and Katharine Hodgson (eds). 2003. Regimes of memory. London and New York: Routledge.

Randhofer, Regina. 2004. By the rivers of Babylon: echoes of the Babylonian past in the musical heritage of the Iraqi Jewish diaspora. Ethnomusicology Forum 13 (1): 21-45.

Redknap, Mark. 2002. Re-creations: visualising our past. Cardiff: National Museum of Wales and Cadw: Welsh Historic Monuments. 
Rees, Helen. 2000. Echoes of history: Naxi music in modern China. Oxford: Oxford University Press.

Rice, Timothy. 1994. May it fill your soul: experiencing Bulgarian music. Chicago and London: University of Chicago Press.

Ricoeur, Paul. 2004. Memory, history, forgetting. Chicago: University of Chicago Press.

Romero, Raúl R. 2001. Debating the past: music, memory, and identity in the Andes. Oxford and New York: Oxford University Press.

Schudson, Michael. 1993. Watergate in American memory: how we remember, forget, and reconstruct the past. New York: Basic Books.

Seeger, Anthony. 1993. When music makes history. In Ethnomusicology and modern music history, edited by Stephen Blum, Philip V. Bohlman and Daniel M. Neuman. Urbana and Chicago: University of Illinois Press, pp. 23-34.

Shanks, Michael. 1992. Experiencing the past: on the character of archaeology. London and New York: Routledge.

Shanks, Michael and Ian Hodder. 1995. Processual, postprocessual and interpretative archaeologies. In Interpreting archaeology: finding meaning in the past, edited by Ian Hodder et al. London and New York: Routledge, pp. 3-29.

Shelemay, Kay Kaufman. 1998. Let jasmine rain down: song and remembrance among Syrian Jews. Chicago and London: University of Chicago Press. . 2001. Toward an ethnomusicology of the early music movement: thoughts on bridging disciplines and musical worlds. Ethnomusicology 45 (1): 1-29.

Slymovics, Susan. 1998. The object of memory: Arab and Jew narrate the Palestinian village. Philadelphia: University of Pennsylvania Press. 
Thomas, Julian. 1995. Where are we now? Archaeological theory in the 1990s. In Theory in archaeology: a world perspective, edited by Peter J. Uko. London and New York: Routledge, pp. 343-62.

Turino, Thomas. 2000. Nationalists, cosmopolitans, and popular music in Zimbabwe. Chicago and London: University of Chicago Press.

Urry, John. 1996. How societies remember the past. In Theorizing museums: representing identity and diversity in a changing world, edited by Sharon Macdonald and Gordon Fyfe. Oxford and Cambridge, MA: Blackwell Publishers/The Sociological Review, pp. 45-65.

Waterman, Christopher Alan. 1990. Jùjú: a social history and ethnography of an African popular music. Chicago and London: University of Chicago Press.

Widdess, Richard. 1992. Historical ethnomusicology. In Ethnomusicology: an introduction, edited by Helen Myers. Basingstoke: The Macmillan Press, pp. 219-37. 